\title{
Investigation of the Presence of $b$ Ions in Electron Capture Dissociation Mass Spectra
}

\author{
Helen J. Cooper \\ School of Biosciences, University of Birmingham, Edgbaston, Birmingham, United Kingdom
}

Previously, we have indicated (Cooper, H.J., et al. Int. J. Mass Spectrom., 2003, 228, 723-728) that electron capture dissociation (ECD) of the doubly protonated peptides, $\mathrm{Leu}_{4}-\mathrm{Sar}_{-} \mathrm{Leu}_{3}-\mathrm{Lys}-\mathrm{OH}$, $\mathrm{Leu}_{4}$-Ala-Leu ${ }_{3}-\mathrm{Lys}-\mathrm{OH}, \mathrm{Gly}_{4}-\mathrm{Sar}-\mathrm{Gly}_{3}-\mathrm{Lys}_{-} \mathrm{NH}_{2}$, and Gly ${ }_{3}-$ Pro-Sar-Gly $-\mathrm{Lys}_{3}-\mathrm{NH}_{2}$, results in abundant $b$ ions, which derive from fragmentation of backbone amide bonds, a nonstandard fragmentation channel in ECD. The instrumental conditions were such that the possibility that collision-induced dissociation processes were contributing to the observed spectra was eliminated. In a separate study (Fung, Y.M.E., et al. Eur. J. Mass Spectrom., 2004, 10, 449-457. ECD of peptides Arg-(Gly $)_{n}-X x x-(G l y)_{n}-A r g$, where Xxx is the amino acid of interest, did not result in $b$ ions. The variation in ECD observed for strikingly similar peptides suggests that the nature of the charge carrier (Arg or Lys) is instrumental in governing the fragmentation channels. Here, we describe the ECD behavior of a suite of model peptides designed such that the nature and position of the charge carrier could be probed. The results suggest that the presence of $b$ ions in ECD spectra is a consequence of both charge carrier and peptide structure. Possible mechanisms for the formation of $b$ ions following electron capture are discussed. (J Am Soc Mass Spectrom 2005, 16, 1932-1940) (c) 2005 American Society for Mass Spectrometry

$\mathrm{T}$ The advent of electron capture dissociation (ECD) [1] Fourier transform ion cyclotron resonance (FT-ICR) [2] mass spectrometry constituted a significant advance in biomolecular analysis. The technique involves irradiation of trapped ions with lowenergy electrons and results in fragmentation of the precursor ions. ECD displays a number of features unique among tandem mass spectrometry (MS/MS) techniques: ECD results in cleavage of peptide backbone $\mathrm{N}-\mathrm{C} \alpha$ bonds to produce $c$ and $z$. (or $c$. and $z$ ) fragment ions, whereas traditional MS/MS techniques cleave peptide backbone amide bonds and form $b$ and $y$ ions $[3,4]$; ECD results in preferential cleavage of disulfide bonds [5]; ECD peptide (protein) backbone fragments retain posttranslational modifications [6], for example, phosphorylation $[7,8]$, glycosylation $[9,10]$, and ubiquitination [11]. Other fragmentation channels observed following electron capture by peptides and proteins include hydrogen atom loss [12], the production of $a$ and $y$ ions [5], and cleavage within amino acid side chains [13].

The mechanism by which ECD of $\mathrm{N}-\mathrm{C} \alpha$ bonds in peptides and proteins occurs has been a matter of considerable debate $[1,5,14-23]$. One proposed mechanism [1] involves capture of an electron by a charged site in the ion, for example, a protonated lysine or

Published online October 25, 2005

Address reprint requests to Helen J. Cooper, School of Biosciences, University of Birmingham, Edgbaston, Birmingham B15 2TT, UK. E-mail: H.J.Cooper@bham.ac.uk arginine residue, followed by $\mathrm{H} \cdot$ transfer to (or recapture by) an amide carbonyl resulting in an aminoketyl radical. The radical subsequently dissociates via cleavage of the $\mathrm{N}-\mathrm{C} \alpha$ bond. Originally, it was suggested that $c / z$. fragment ion formation proceeded faster than vibrational energy redistribution, and that the process was nonergodic [1]. Recent work by Tureček suggests that $\mathrm{N}-\mathrm{C} \alpha$ bond dissociation is particularly facile in thermalized radicals and radical cations, that is, nonergodicity does not apply [21]. McLafferty and coworkers [24] showed that infrared multiphoton dissociation of thermalized $[\mathrm{M}+12 \mathrm{H}]^{11+\cdot}$ ions results in the dominant loss of $\mathrm{H} \cdot$ atoms in marked contrast to the $c / z$ ions produced following electron capture by $[\mathrm{M}+12 \mathrm{H}]^{12+}$ ions to form $[\mathrm{M}+12 \mathrm{H}]^{11+}$ radical ions. These researchers concluded that ECD was nonergodic and the mechanism involves electron capture in a high- $n$ Rydberg state followed by cooling to a dissociative electronic state. A direct mechanism has been suggested in which electron capture at $\mathrm{C}_{\mathrm{OH}}^{+}$is accompanied by cleavage of the $\mathrm{N}-\mathrm{C} \alpha$ bond. Uggerud and coworkers $[25,26]$ have shown theoretically and experimentally that both hydrogen transfer and direct processes play a role in ECD. Recently, Syrstad and Tureček [27] have proposed a mechanism for ECD that explains the low selectivity of $\mathrm{N}-\mathrm{C} \alpha$ cleavage and applies equally to peptide ions whose charge carriers are not protons. Either electron capture in a ground electronic state results in hydrogen atom transfer from the ammonium group to the amide carbonyl to which it is solvated or electron capture in 
excited electronic states results in formation of an amide suberbase that abstracts a proton from an accessible site.

Previous work in our laboratory showed that ECD of the doubly protonated peptides $\mathrm{Leu}_{4}-\mathrm{Sar}-\mathrm{Leu}_{3}-\mathrm{Lys}-\mathrm{OH}$, $\mathrm{Leu}_{4}$-Ala-Leu 3 -Lys-OH, Gly - Sar-Gly 3 -Lys- $\mathrm{NH}_{2}$, and $\mathrm{Gly}_{3}$-Pro-Sar-Gly ${ }_{3}-\mathrm{Lys}-\mathrm{NH}_{2}$, results in extensive secondary fragmentation [28]. The $w$ ions resulting from dissociation of $z$. ions were observed. (The formation of $w$ ions has also been observed in hot ECD [29], a related technique that uses higher energy electrons than ECD). In addition to $w$ ions, entire and, in some cases multiple cleavages of amino acid side chains from backbone fragments were observed. Extensive water loss from backbone fragments was observed for the glycine-rich peptides. For $\mathrm{Leu}_{4}-\mathrm{Ala}-\mathrm{Leu}_{3}-\mathrm{Lys}-\mathrm{OH}$, the preferred fragmentation channel was cleavage of the amide bond to produce $b_{7}$ and $b_{8}$ ions. ECD of the peptides $\operatorname{Leu}_{4}{ }^{-}$ Sar-Leu ${ }_{3}-\mathrm{Lys}-\mathrm{OH}, \mathrm{Gly}_{4}-\mathrm{Sar}_{-} \mathrm{Gly}_{3}-\mathrm{Lys}-\mathrm{NH}_{2}$, and $\mathrm{Gly}_{3}-$ Pro-Sar-Gly ${ }_{3}-\mathrm{Lys}_{-} \mathrm{NH}_{2}$ also revealed the presence of abundant $b$ ions. Fragmentation of the peptide amide bond to form $b$ ions is a nonstandard ECD channel. Occasionally, $b$ ions are observed in ECD spectra and their presence has been ascribed to collision-induced dissociation (CID) processes [30, 31]. For example, we have previously observed fragments deriving from facile bond cleavages, e.g., N-terminal to proline. Those fragments were observed in experiments in which stored waveform inverse Fourier transform (SWIFT) isolation and long irradiation times (30 s) were used. Instrumental conditions (quadrupole isolation and millisecond electron irradiation period) in both of our previous study [28] and the current work were such that the possibility that CID processes were contributing to the observed spectra was eliminated.

Recently, Chan and coworkers published a comparative study of CID and ECD of some model peptides [32]. ECD of the peptides Arg-Gly ${ }_{3}-\mathrm{Trp}-\mathrm{Gly}_{3}-\mathrm{Arg}$, Arg$\mathrm{Gly}_{3}-\mathrm{Asp}-\mathrm{Gly}_{3}-\mathrm{Arg}$, and Arg-Gly $\mathrm{H}_{3} \mathrm{Glu}-\mathrm{Gly}_{3}$-Arg resulted in full sequence coverage of $c$ and $z$. fragment ions. No $b$ ions were observed. The variation in ECD observed for strikingly similar peptides suggests that the nature of the charge carrier (Arg or Lys) may be instrumental in governing the fragmentation channels. Further evidence to support this hypothesis arises from the ECD spectrum obtained from Lys-Gly Lrp-Gly $_{3}-$ Lys, in which the $b_{8}$ ion is observed [32]. Precursor ion selection was achieved by correlated sweep ejection (COSE). Electron irradiation time was 30-100 ms.

Iavorone et al. [33] studied the effect of charge state and cationizing agent on the ECD of the peptide Ac(Ala-Lys-Ala-Ala-Lys) $)_{3}-A l a-\mathrm{NH}_{2}$. ECD of the $[\mathrm{M}+$ $2 \mathrm{H}]^{2+}$ and $[\mathrm{M}+3 \mathrm{H}]^{3+}$ ions did not result in $b$ ions. However, $b$ ions were observed in the ECD spectra of the $4+$ and $5+$ parent ions. Whether these $b$ ions are the result of ECD or CID processes is unclear: ion trapping in the ICR cell was enhanced by use of a nitrogen pulse. Selection of the precursor ion was achieved by COSE. Electron irradiation times varied between $500 \mathrm{~ms}$ and $5 \mathrm{~s}$.
Here, we investigate the effect of the nature and position of the charge carrier on the ECD spectra of a suite of model peptides: $\mathrm{Leu}_{4}$-Pro-Leu $\mathrm{L}_{4}$-Lys, Leu $\mathrm{L}_{4}$-Pro$\mathrm{Leu}_{4}$-Arg, Gly -Pro-Gly $_{4}$-Lys, Gly -Pro-Gly $_{4}$-Arg, Lys$\mathrm{Leu}_{4}-\mathrm{Pro}_{-\mathrm{Leu}_{4} \text {, and Arg-Leu }}-\mathrm{Pro}_{-} \mathrm{Leu}_{4}$. Peptide ions were doubly charged, that is, the charged sites were the terminal amino group and the side chain of the basic residue, either Lys or Arg. The peptides were designed such that the position of the basic residue, $\mathrm{N}$ - or C-terminal, could be investigated. The effect of amino acid side chain, Gly or Leu, was also examined. The phenomenon of proline $c / z$ cleavage observed previously [28] was investigated by inclusion of Pro residues in the peptides. Substance P (Arg-Pro-Lys-Pro-Gln-GlnPhe-Phe-Gly-Leu-Met- $\mathrm{NH}_{2}$ ) and its all-Lys (Lys-ProLys-Pro-Gln-Gln-Phe-Phe-Gly-Leu-Met-NH ${ }_{2}$ ) and allArg (Arg-Pro-Arg-Pro-Gln-Gln-Phe-Phe-Gly-Leu-Met$\mathrm{NH}_{2}$ ) counterparts were also investigated. The results suggest that electron capture-mediated production of $b$ fragments is dependent not only on the charge carrier, but also on the peptide ion structure. Possible mechanisms for dissociation of peptide ions to $b$ fragments following electron capture are discussed.

\section{Experimental Methods}

\section{Samples}

Substance P was purchased from Sigma (St. Louis, MO) and used without further purification. Peptides $\mathrm{Leu}_{4}$ Pro-Leu 4 -Lys, Leu Lro-Leu $_{4}$-Arg, Gly -Pro-Gly $_{4}$-Lys, $\mathrm{Gly}_{4}$-Pro-Gly 4 -Arg, Lys-Leu -Pro-Leu $_{4}$, Arg-Leu -Pro- $^{-}$ $\mathrm{Leu}_{4}$, Lys-Pro-Lys-Pro-Gln-Gln-Phe-Phe-Gly-Leu-Met$\mathrm{NH}_{2}$, and Arg-Pro-Arg-Pro-Gln-Gln-Phe-Phe-Gly-LeuMet- $\mathrm{NH}_{2}$ were synthesized by American Peptide Co., Inc., (Sunnyvale, CA) and used without further purification. The peptides were microelectrosprayed at 10 $\mu \mathrm{M}$ from solutions of 1:1 water/acetonitrile (J. T. Baker, Philipsburg, NJ), 1\% formic acid (Aldrich, Milwaukee, WI).

\section{ECD FT-ICR Mass Spectrometry}

Experiments were performed on a homebuilt, passively shielded, 9.4 Tesla FT-ICR mass spectrometer [34] (NHMFL, Tallahassee, FL) equipped with an external microelectrospray ionization source [35]. Electrospray ionization (ESI) of the samples was performed by use of a NanoMate autosampler/ESI source (Advion Biosciences, Ithaca, NY). The equipment was operated remotely at the University of Birmingham, UK, as described previously [36]. Electrosprayed ions were delivered into the mass spectrometer through a Chaitstyle atmosphere-to-vacuum interface [37] and externally accumulated [35] in an rf-only octapole. Ions were transferred through multipole ion guides and trapped in an open [38] cylindrical cell (Malmberg-Penning trap) [39]. A front-end resolving quadrupole [40] served to isolate the peptide ion under investigation. 


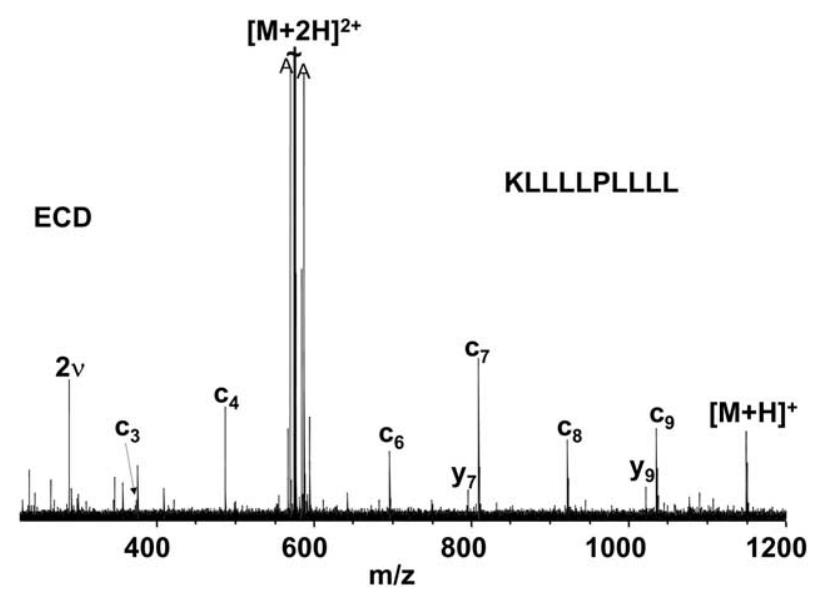

Figure 1. ECD FT-ICR mass spectrum of $[\mathrm{M}+2 \mathrm{H}]^{2+}$ ions of peptide $\mathrm{Lys}_{-} \mathrm{Leu}_{4}$-Pro-Leu ${ }_{4}$. Mass spectrum calibrated against the parent and charge-reduced $[\mathrm{M}+\mathrm{H}]^{+}$ions. $\mathrm{A}=$ singly charged ions not removed in isolation; $2 \nu=$ second harmonic.

An indirectly heated dispenser cathode (Heat Wave, Watsonville, CA) mounted on the central axis of the system provided the electrons for ECD [41]. A potential of either -2.0 or $-5.0 \mathrm{~V}$ was applied to the cathode during the irradiation event. A grid situated in front of the filament was kept at $-200 \mathrm{~V}$ for most of the experiment and pulsed to $+50 \mathrm{~V}$ during the ECD event. The ICR trapping potential was $10 \mathrm{~V}$ during the ECD event. The isolated parent ions were irradiated with electrons for 2-20 ms. These parameters correspond to the minimum conditions required for ECD of these peptide ions. For the double resonance experiments, fragment $c_{n}$ ions were ejected continuously from the ICR cell throughout the ECD and electron cleanup events by resonant single-frequency dipolar excitation at $1019.80 \mathrm{kHz}\left(c_{9}\right), 906.70 \mathrm{kHz}\left(c_{8}\right)$, or $793.60 \mathrm{kHz}\left(c_{7}\right)$ (0. 05 peak-to-peak voltage $\left.\left(\mathrm{V}_{\mathrm{p}-\mathrm{p}}\right)\right)$.

Ions were frequency-sweep ("chirp") [42] excited and detected in direct mode (512 kword time-domain data). Between 20 and 50 time-domain data sets were

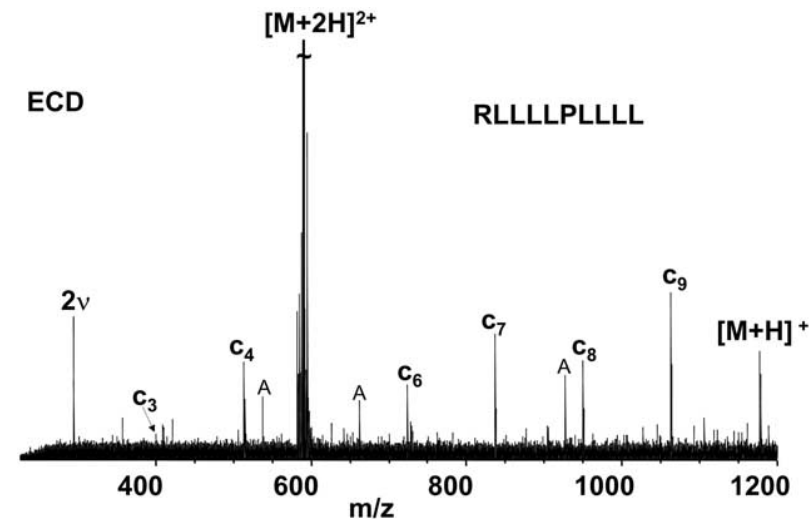

Figure 2. ECD FT-ICR mass spectrum of $[\mathrm{M}+2 \mathrm{H}]^{2+}$ ions of peptide Arg-Leu -Pro-Leu $_{4}$. Mass spectrum calibrated against the parent and charge-reduced $[\mathrm{M}+\mathrm{H}]^{+}$ions. $\mathrm{A}=$ noise spikes; $2 \nu=$ second harmonic.
Table 1. Fragments observed following ECD of $[\mathrm{M}+2 \mathrm{H}]^{2+}$ ions of KLLLLPLLLL

\begin{tabular}{lrrc}
\hline \multicolumn{1}{c}{ Fragment ion } & $\mathrm{m} / \mathrm{z}_{\text {meas }}$ & $\mathrm{m} / \mathrm{z}_{\text {calc }}$ & $\Delta \mathrm{m} / \mathrm{ppm}$ \\
\hline \hline$c_{3}$ & 372.2972 & 372.2975 & 0.8 \\
$c_{4}$ & 485.3812 & 485.3815 & 0.6 \\
Parent $[\mathrm{M}+2 \mathrm{H}]^{2+}$ & 574.9229 & 574.9229 & \\
$c_{6}$ & 695.5184 & 695.5184 & 0.0 \\
$c_{7}$ & 808.6019 & 808.6024 & 0.7 \\
$c_{8}$ & 921.6855 & 921.6865 & 1.1 \\
$c_{9}$ & 1034.7696 & 1034.7710 & 1.3 \\
{$[\mathrm{M}+\mathrm{H}]^{+}$} & 1148.8386 & 1148.8386 & \\
\hline
\end{tabular}

Mass spectrum calibrated against the parent and charge-reduced [M + $\mathrm{H}]^{+}$ions.

co-added, Hanning apodized, zero-filled once, and subjected to fast Fourier transform followed by magnitude calculation. The experimental event sequence was controlled by a modular ICR data acquisition system (MIDAS) [43]. The FT-ICR mass spectra were internally frequency-to- $m / z$ calibrated $[44,45]$ with respect to the precursor ion and the charge reduced species (either [M $+\mathrm{H}]^{+}$or $[\mathrm{M}+2 \mathrm{H}]^{+*}$ ) or backbone fragments. The FT-ICR mass spectra were analyzed by use of the MIDAS analysis software package [46].

\section{Results and Discussion}

Figures 1-6 show the FT-ICR mass spectra obtained following ECD of $[\mathrm{M}+2 \mathrm{H}]^{2+}$ ions of the peptides Lys-Leu $_{4}-$ Pro-Leu $_{4}$, Arg-Leu 4 -Pro-Leu ${ }_{4}$, Leu $_{4}-$ Pro-Leu $_{4}-$ Lys, $\mathrm{Leu}_{4}-\mathrm{Pro}_{-\mathrm{Leu}_{4}-\mathrm{Arg} \text {, Gly }}-\mathrm{Pro}_{-} \mathrm{Gly}_{4}-\mathrm{Lys}$, and $\mathrm{Gly}_{4}-$ Pro-Gly ${ }_{4}$-Arg. Summaries of the backbone fragments observed are given in Tables 1 through 6. Figure 7 shows the FT-ICR mass spectrum obtained following ECD of $[\mathrm{M}+2 \mathrm{H}]^{2+}$ ions of the peptide substance $\mathrm{P}$ and its analogs-one containing two lysine residues and the other containing two arginine residues.

The ECD spectra obtained from the peptides Lys$\mathrm{Leu}_{4}-\mathrm{Pro}_{-\mathrm{Leu}_{4}}$ and Arg-Leu 4 -Pro-Leu ${ }_{4}$ (Figures 1 and 2; Tables 1 and 2) reveal that the dominant pathway is cleavage to form $c$ fragments. Protonation of peptides occurs at basic amino acid residues (typically lysine and/or arginine, but also in some cases histidine) or on the amino group at the N-terminus. Therefore, the

Table 2. Fragments observed following ECD of $[\mathrm{M}+2 \mathrm{H}]^{2+}$ ions of RLLLLPLLLL

\begin{tabular}{lccc}
\hline \multicolumn{1}{c}{ Fragment ion } & $\mathrm{m} / \mathrm{z}_{\text {meas }}$ & $\mathrm{m} / \mathrm{z}_{\text {calc }}$ & $\Delta \mathrm{m} / \mathrm{ppm}$ \\
\hline \hline$c_{3}$ & 400.3036 & 400.3036 & 0 \\
$c_{4}$ & 513.3874 & 513.3877 & 0.6 \\
Parent $[\mathrm{M}+2 \mathrm{H}]^{2+}$ & 588.9260 & 588.9260 & \\
$c_{6}$ & 723.5239 & 723.5245 & 0.8 \\
$c_{7}$ & 836.6078 & 836.6086 & 0.9 \\
$c_{8}$ & 949.6919 & 949.6926 & 0.7 \\
$c_{9}$ & 1062.7740 & 1062.777 & 2.2 \\
{$[\mathrm{M}+\mathrm{H}]^{+}$} & 1176.8448 & 1176.8448 & \\
\hline
\end{tabular}

Mass spectrum calibrated against the parent and charge-reduced [M + $\mathrm{H}]^{+}$ions. 


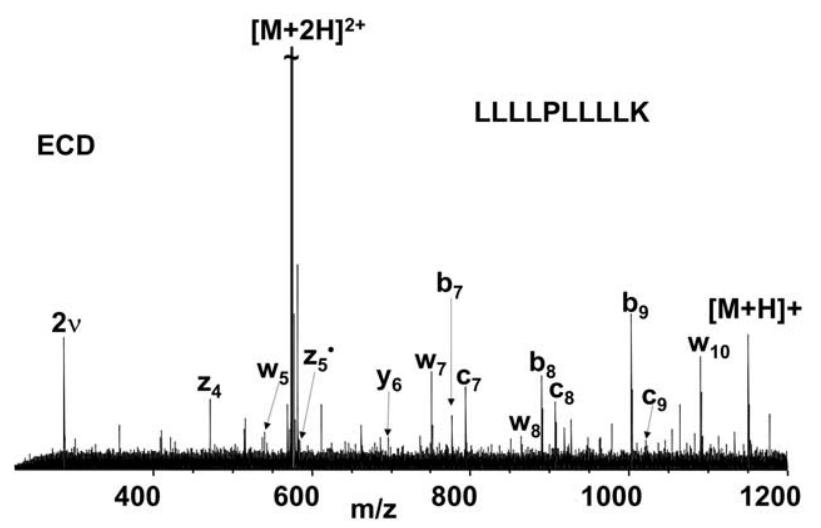

Figure 3. ECD FT-ICR mass spectrum of $[\mathrm{M}+2 \mathrm{H}]^{2+}$ ions of peptide $\mathrm{Leu}_{4}$-Pro-Leu ${ }_{4}$-Lys. Mass spectrum calibrated against the parent and charge-reduced $[\mathrm{M}+\mathrm{H}]^{+}$ions. $2 \nu=$ second harmonic.

peptides Lys-Leu ${ }_{4}-\mathrm{Pro}_{\mathrm{Leu}}{ }_{4}$ and $\mathrm{Arg}-\mathrm{Leu}_{4}-\mathrm{Pro}^{-\mathrm{Leu}_{4}}$ would be expected to be protonated at the $\mathrm{N}$-terminal amino group and the side chain of the $\mathrm{N}$-terminal amino acid (Lys and Arg, respectively). The charge distribution explains the characteristic feature of the ECD mass spectra, namely, that exclusively $\mathrm{N}$-terminal fragments are observed. Regardless of which proton captures the electron, the charge remains at the Nterminus. Subsequent cleavage of the peptide backbone will result in charged $c$ fragments and neutral $z$ fragments that can not be detected by the mass spectrometer [47]. No $b$ ions were observed for either peptide. The $y_{7}$ and $y_{9}$ ions were observed for the Lys peptide. The production of $a$ and $y$ ions is a minor fragmentation channel in ECD [5].

Figure 3 shows the ECD spectrum obtained from [M $+2 \mathrm{H}]^{2+}$ ions of peptide $\mathrm{Leu}_{4}$-Pro-Leu 4 -Lys (See also Table 3). The most abundant fragment peak corresponds to $b_{9}$ ions. Peaks corresponding to $b_{8}$ and $b_{7}$ are observed at a lower abundance. In addition, peaks corresponding to $c, z$, and $w$ ions are observed. The presence of both $\mathrm{N}$ - ( $c$ ions) and C-terminal fragments $(z$ and $w$ ions) is indicative of the charging pattern, that is,

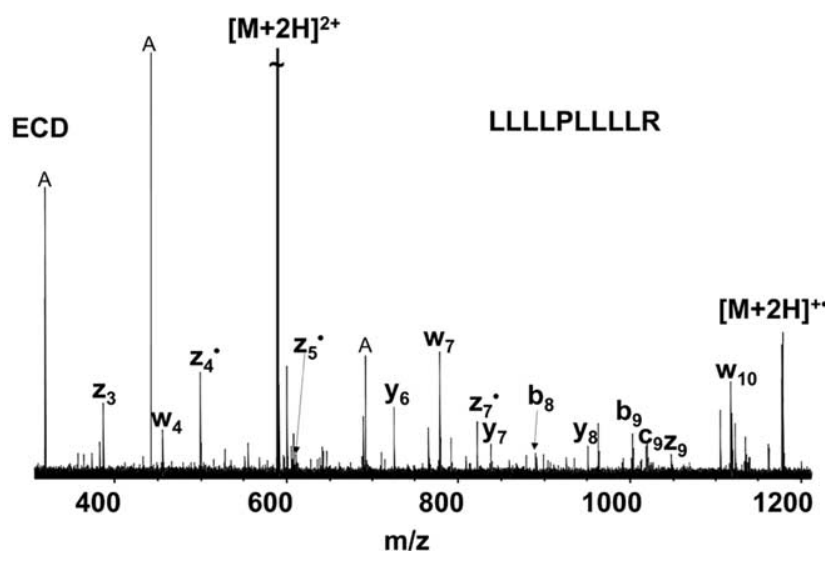

Figure 4. ECD FT-ICR mass spectrum of $[\mathrm{M}+2 \mathrm{H}]^{2+}$ ions of peptide $\mathrm{Leu}_{4}$-Pro-Leu ${ }_{4}$-Arg. Mass spectrum calibrated against the parent and charge-reduced $[\mathrm{M}+2 \mathrm{H}]^{+}$ions. $\mathrm{A}=$ noise spikes.
Table 3. Fragments observed following ECD of $[\mathrm{M}+2 \mathrm{H}]^{2+}$ ions of LLLLPLLLLK

\begin{tabular}{lccc}
\hline \multicolumn{1}{c}{ Fragment ion } & $\mathrm{m} / \mathrm{z}_{\text {meas }}$ & $\mathrm{m} / \mathrm{z}_{\text {calc }}$ & $\Delta \mathrm{m} / \mathrm{ppm}$ \\
\hline \hline$z_{4}$ & 471.3547 & 471.3546 & 0.1 \\
$w_{5}$ & 540.3761 & 540.3761 & 0 \\
Parent $[\mathrm{M}+2 \mathrm{H}]^{2+}$ & 574.9229 & 574.9229 & \\
$z_{5} \cdot$ & 583.4311 & 583.4309 & 0.3 \\
$z_{7^{*}}-2\left(\mathrm{C}_{4} \mathrm{H}_{8}\right)$ & 681.4410 & 681.4425 & 2.2 \\
$y_{6}$ & 696.5031 & 696.5024 & 1.1 \\
$z_{7} \cdot \mathrm{C}_{4} \mathrm{H}_{8}$ & 737.5068 & 737.5051 & 2.3 \\
$w_{7}$ & 750.5132 & 750.5129 & 0.3 \\
$b_{7}$ & 776.5647 & 776.5650 & 0.3 \\
$c_{7}$ & 793.5906 & 793.5915 & 1.1 \\
$w_{8}$ & 863.5971 & 863.5970 & 0.1 \\
$b_{8}$ & 889.6500 & 889.6490 & 1.1 \\
$c_{8}$ & 906.6743 & 906.6756 & 1.4 \\
$y_{8}$ & 922.6725 & 922.6756 & 3.4 \\
$z_{9} \cdot \mathrm{C}_{4} \mathrm{H}_{8}$ & 963.6764 & 963.6734 & 3.1 \\
$b_{9}$ & 1002.7341 & 1002.7331 & 0.9 \\
$c_{9}$ & 1019.7581 & 1019.7596 & 1.4 \\
$w_{10}$ & 1089.7672 & 1089.7651 & 1.9 \\
{$[\mathrm{M}+\mathrm{H}]^{+}$} & 1148.8386 & 1148.8386 & \\
\hline
\end{tabular}

Mass is spectrum calibrated against the parent and charge-reduced [M $+\mathrm{H}]^{+}$ions.

protonation at the $\mathrm{N}$-terminal amino group and the side chain of the C-terminal basic residue. The ECD spectrum for the Arg equivalent peptide (Figure 4, Table 4) also reveals the presence of $b$ ions, in particular $b_{9}$; however, these ions do not constitute the major products of ECD. Again, the ECD of doubly protonated

Table 4. Fragments observed following ECD of $[\mathrm{M}+2 \mathrm{H}]^{2+}$ ions of LLLLPLLLLR

\begin{tabular}{|c|c|c|c|}
\hline Fragment ion & $\mathrm{m} / \mathrm{z}_{\text {meas }}$ & $\mathrm{m} / \mathrm{z}_{\text {calc }}$ & $\Delta m / p p m$ \\
\hline$z_{3}$ & 386.2758 & 386.2767 & 2.3 \\
\hline$b_{4}$ & 453.3437 & 453.3441 & 0.9 \\
\hline$w_{4}$ & 455.2975 & 455.2982 & 1.5 \\
\hline$z_{4}^{i}$ & 498.3525 & 498.3530 & 1.0 \\
\hline$z_{5} \cdot-\mathrm{C}_{4} \mathrm{H}_{8}$ & 555.3739 & 555.3744 & 0.9 \\
\hline$w_{5}$ & 568.3822 & 568.3823 & 0.1 \\
\hline$[\mathrm{M}+2 \mathrm{H}]^{2+}$ & 588.9260 & 588.9260 & \\
\hline$z_{5}$ & 611.4351 & 611.4370 & 3.0 \\
\hline$z_{7^{*}}-2\left(\mathrm{C}_{4} \mathrm{H}_{8}\right)$ & 709.4503 & 709.4487 & 2.2 \\
\hline$y_{6}$ & 724.5087 & 724.5085 & 0.3 \\
\hline$z_{7^{*}}-\mathrm{C}_{4} \mathrm{H}_{8}$ & 765.5120 & 765.5113 & 0.9 \\
\hline$b_{7}$ & 776.5663 & 776.5650 & 1.6 \\
\hline$w_{7}$ & 778.5197 & 778.5191 & 0.7 \\
\hline$z_{7}^{\prime}$ & 821.5737 & 821.5739 & 0.2 \\
\hline$y_{7}$ & 837.5934 & 837.5926 & 1.0 \\
\hline $\mathrm{Z}_{8} \cdot-\mathrm{C}_{4} \mathrm{H}_{8}$ & 878.5980 & 878.5953 & 3.0 \\
\hline$b_{8}$ & 889.6493 & 889.6490 & 0.4 \\
\hline$w_{8}$ & 891.6035 & 891.6031 & 0.4 \\
\hline$y_{8}$ & 950.6754 & 950.6766 & 1.3 \\
\hline$z_{9^{*}}-\mathrm{C}_{4} \mathrm{H}_{8}$ & 991.6816 & 991.6794 & 2.2 \\
\hline$b_{9}$ & 1002.7337 & 1002.7330 & 0.7 \\
\hline$c_{9}$ & 1019.7589 & 1019.7600 & 1.0 \\
\hline$w_{10}$ & 1117.7734 & 1117.7713 & 1.9 \\
\hline$[\mathrm{M}+2 \mathrm{H}]^{+\cdot}$ & 1177.8530 & 1177.8530 & \\
\hline
\end{tabular}

Mass spectrum is calibrated against the parent and charge-reduced [M $+2 \mathrm{H}]^{+\cdot}$ ions. 


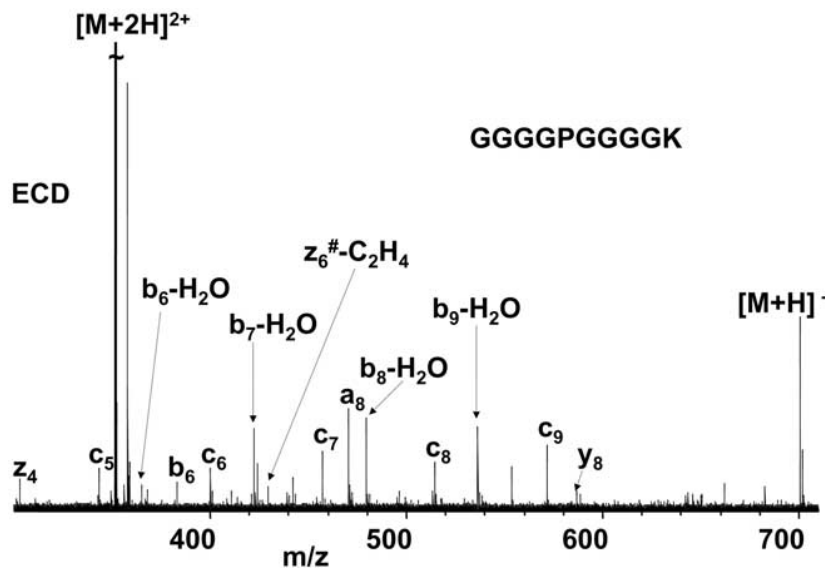

Figure 5. ECD FT-ICR mass spectrum of $[\mathrm{M}+2 \mathrm{H}]^{2+}$ ions of peptide $\mathrm{Gly}_{4}$-Pro-Gly 4 -Lys. Mass spectrum calibrated against the parent and charge-reduced $[\mathrm{M}+\mathrm{H}]^{+}$ions. \#, denotes diradical.

$\mathrm{Leu}_{4}$-Pro-Leu ${ }_{4}$-Arg ions results in extensive secondary fragmentation and the formation of $w$ ions.

The ECD spectra obtained from the peptides $\mathrm{Gly}_{4}{ }^{-}$ Pro-Gly ${ }_{4}$-Lys-and Gly $_{4}$-Pro-Gly 4 -Arg are shown in Figures 5 and 6 (see also Tables 5 and 6). The dominant fragmentation channel for the Lys peptide is the production of $b$ ions accompanied by the loss of water. In addition, $c, z$, and $y$ ions are observed. For the Arg peptide, the spectrum is more complex with peaks corresponding to $c, z, y$, and $b$ ions, although the latter do not dominate.

Figure 7 shows the ECD spectra obtained from doubly protonated substance $\mathrm{P}$ and its lysine and arginine analogs. The fragments are summarized in Table 7. Each of these spectra reveals dissociation to predominantly $c$ fragments with some contribution from the $z_{g}$ fragments.

The primary purpose of this study was the investigation of the production of $b$ ions following electron capture. The $b$ ions observed in the ECD spectra presented here were not the product of CID processes. Precursor ion isolation was achieved through use of a

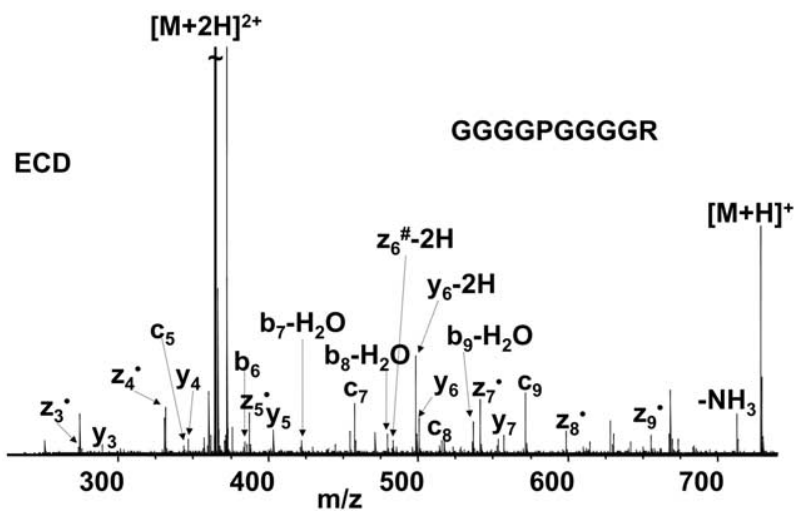

Figure 6. ECD FT-ICR mass spectrum of $[\mathrm{M}+2 \mathrm{H}]^{2+}$ ions of peptide $\mathrm{Gly}_{4}-\mathrm{Pro}-\mathrm{Gly}_{4}$-Arg. Mass spectrum calibrated against the parent and charge-reduced $[\mathrm{M}+\mathrm{H}]^{+}$ions. \#, denotes diradical.
Table 5. Fragments observed following ECD of $[\mathrm{M}+2 \mathrm{H}]^{2+}$ ions of GGGGPGGGGK

\begin{tabular}{llcc}
\hline \multicolumn{1}{c}{ Fragment ion } & $m / z_{\text {meas }}$ & $m / z_{\text {calc }}$ & $\Delta m / p p m$ \\
\hline \hline$z_{4}$ & 303.1666 & 303.1668 & 0.9 \\
$c_{5}$ & 343.1727 & 343.1730 & 0.9 \\
Parent $[\mathrm{M}+2 \mathrm{H}]^{2+}$ & 350.6725 & 350.6725 & \\
$b_{6}-\mathrm{H}_{2} \mathrm{O}$ & 365.1568 & 365.1573 & 1.5 \\
$b_{6}$ & 383.1677 & 383.1679 & 0.5 \\
$c_{6}$ & 400.194 & 400.1945 & 1.2 \\
$b_{7}-\mathrm{H}_{2} \mathrm{O}$ & 422.1785 & 422.1788 & 0.7 \\
$z_{6}^{\#}-\mathrm{C}_{2} \mathrm{H}_{4}$ & 429.2095 & 429.2098 & 0.7 \\
$c_{7}$ & 457.2156 & 457.2159 & 0.7 \\
$a_{8}$ & 470.2361 & 470.2364 & 0.7 \\
$b_{8}-\mathrm{H}_{2} \mathrm{O}$ & 479.1999 & 479.2002 & 0.7 \\
$c_{8}$ & 514.237 & 514.2374 & 0.7 \\
$b_{9}-\mathrm{H}_{2} \mathrm{O}$ & 536.2215 & 536.2217 & 0.5 \\
$c_{9}$ & 571.2583 & 571.2588 & 0.9 \\
$y_{8}$ & 586.2947 & 586.2949 & 0.3 \\
{$[\mathrm{M}+\mathrm{H}]^{+}$} & 700.3378 & 700.3378 & \\
\hline
\end{tabular}

Mass spectrum is calibrated against the parent and charge-reduced [M $+\mathrm{H}]^{+}$ions. \#, denotes diradical.

resolving quadrupole before trapping in the ICR cell. No waveforms (SWIFT, COSE, etc.) were applied; thus, the trapped ions were not excited. Activated ion techniques were not applied. Precursor ions fragmented as a result of low-energy electron irradiation only. To confirm this, for each ECD experiment, a second experiment was performed that was identical except that the

Table 6. Fragments observed following ECD of $[\mathrm{M}+2 \mathrm{H}]^{2+}$ ions of GGGGPGGGGR

\begin{tabular}{lccc}
\hline \multicolumn{1}{c}{ Fragment ion } & $m / z_{\text {meas }}$ & $m / z_{\text {calc }}$ & $\Delta m / \mathrm{ppm}$ \\
\hline \hline$z_{3} \cdot$ & 273.1435 & 273.1437 & 0.9 \\
$y_{3}$ & 289.1622 & 289.1624 & 0.8 \\
$z_{4} \cdot c_{5}$ & 330.1650 & 330.1652 & 0.5 \\
$y_{4}$ & 343.1725 & 343.1730 & 1.5 \\
{$[\mathrm{M}+2 \mathrm{H}]^{2+}$} & 346.1836 & 346.1839 & 1.0 \\
$b_{6}-\mathrm{H}_{2} \mathrm{O}$ & 364.6756 & 364.6756 & \\
$b_{6}$ & 365.1580 & 365.1573 & 1.8 \\
$z_{5}$ & 383.1678 & 383.1679 & 0.4 \\
$y_{5}$ & 387.1864 & 387.1866 & 0.4 \\
$b_{7}-\mathrm{H}_{2} \mathrm{O}$ & 403.2051 & 403.2054 & 0.7 \\
$c_{7}$ or $_{6}{ }^{\#}-\mathrm{C}_{2} \mathrm{H}_{4}$ & 422.1788 & 422.1788 & 0.0 \\
$a_{8}+\mathrm{H}$ or $z_{6}^{\#}-\mathrm{CH}_{2}$ & 457.2157 & 457.2159 & 0.5 \\
$b_{8}-\mathrm{H}_{2} \mathrm{O}$ & 471.2315 & 471.2315 & 0.2 \\
$z_{6}^{\#}-2 \mathrm{H}$ & 483.2314 & 479.2002 & 0.2 \\
$y_{6}-2 \mathrm{H}$ & 498.2423 & 498.2316 & 0.5 \\
$y_{6}$ & 500.2580 & 500.2581 & 0.3 \\
$c_{8}$ & 514.2376 & 514.2374 & 0.3 \\
$b_{9}-\mathrm{H}_{2} \mathrm{O}$ & 536.2216 & 536.2217 & 0.4 \\
$z_{7}$ & 541.2608 & 541.2609 & 0.2 \\
$y_{7}$ & 557.2793 & 557.2796 & 0.2 \\
$c_{9}$ & 571.2587 & 571.2588 & 0.1 \\
$z_{8}$ & 598.2822 & 598.2823 & 0.2 \\
$y_{8}$ & 614.3004 & 614.3010 & 1.0 \\
$z_{9}$ & 655.3037 & 655.3034 & 0.5 \\
{$\left[\mathrm{M}+\mathrm{H}^{+}\right.$} & 728.3440 & 728.3440 & \\
\hline
\end{tabular}

Mass spectrum is calibrated against the parent and charge-reduced [M $+\mathrm{H}]^{+}$ions. \#, denotes diradical. 

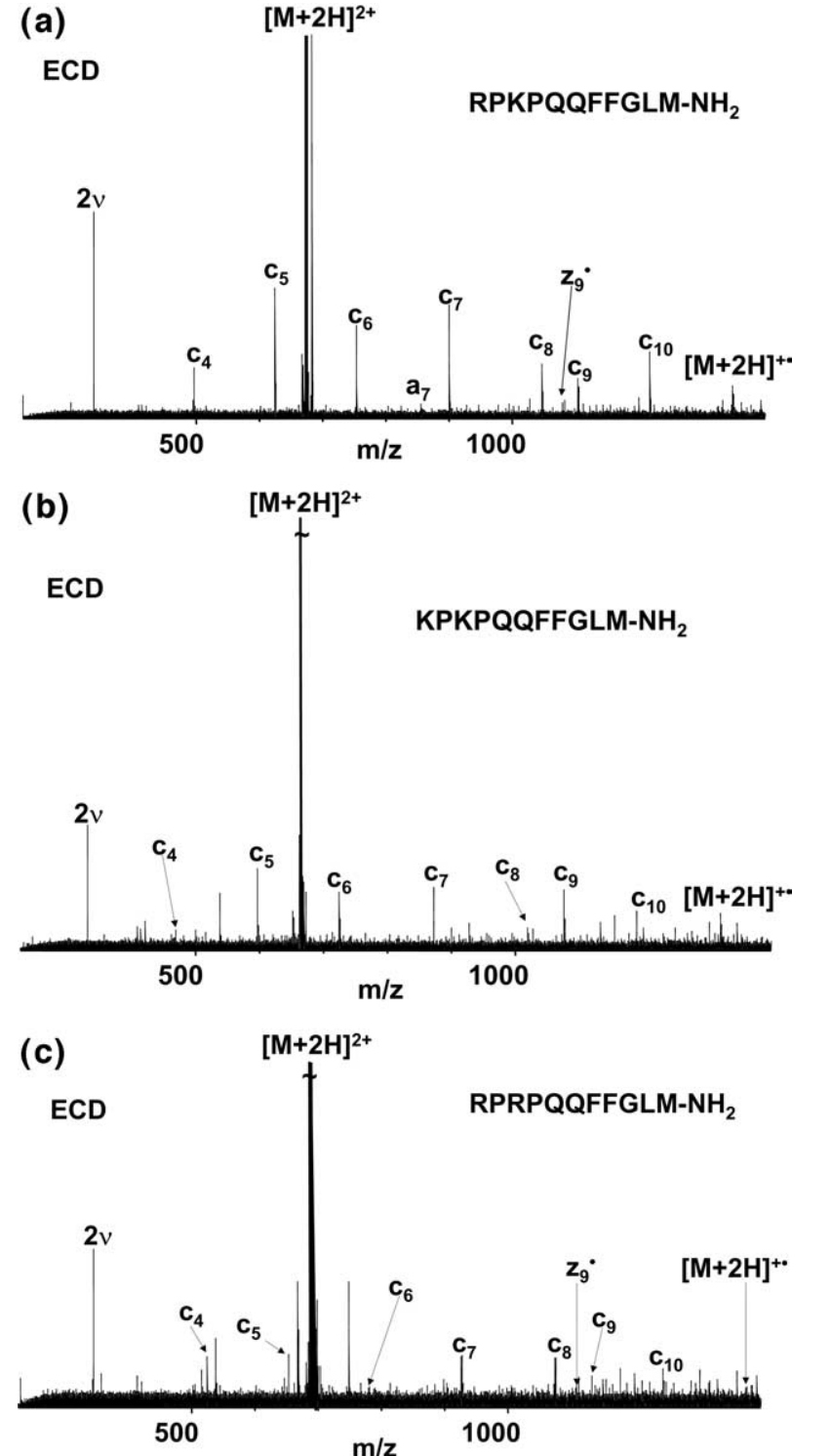

Figure 7. ECD FT-ICR mass spectra of $[\mathrm{M}+2 \mathrm{H}]^{2+}$ ions of peptides substance P RPKPQQFFGLM-NH ${ }_{2}$ (a); KPKPQQFFGLM$\mathrm{NH}_{2}$ (b); and RPRPQQFFGLM-NH $\mathrm{N}_{2}$ (c). Mass spectra calibrated against the parent and charge-reduced $[\mathrm{M}+2 \mathrm{H}]^{+}$ions. $2 \nu=$ second harmonic.

grid potential remained at $-200 \mathrm{~V}$ during the notional ECD event, that is, no electrons entered the ICR cell. No fragments were observed for any peptide.

If the production of $b$ ions is not the result of CID processes, these fragments must be the result of electron capture. Uggerud and coworkers recently performed a number of model calculations [25]. Their results suggested that if the precursor ion was N-protonated, the products of electron capture would be $b$ and $y$ ions. It is possible then that the $b$ ions observed in our experiments are the result of fragmentation of N-protonated precursor peptide ions. Alternatively, it may be that the $b$ ions observed are the products of secondary fragmentation, possibly because of infrared irradiation from the heated dispenser cathode, i.e., the $b$ ions result from cleavage within $c$ ions. To investigate this, we performed double resonance experiments on the peptide $\mathrm{Leu}_{4}$-Pro-Leu ${ }_{4}$-Lys. During the ECD event, and the subsequent electron cleanup event, $c_{n}(n=7,8$, and 9) ions were ejected continuously from the ICR cell by resonant single-frequency dipolar excitation at the frequency corresponding to the particular $c_{n}$ ion. Any product ion resulting from fragmentation of that $c_{n}$ ion will not be observed in the resulting mass spectrum. In each case, the putative secondary $b_{n}$ ion was still present in the ECD mass spectrum. The mass spectrum obtained following simultaneous ECD of [ $\mathrm{Leu}_{4}$-Pro$\mathrm{Leu}_{4}$-Lys $\left.+2 \mathrm{H}\right]^{2+}$ and excitation of the $c_{9}$ fragment ions is shown in Figure 8. These results suggest that either the $b$ ions are not the result of secondary fragmentation of $c$ ions or that secondary fragmentation of the $c$ ion occurs before ejection.

A common, but minor, fragmentation channel following electron capture by peptide ions results in the production of $a$. ions [5]. Possibly, $a$. ions are the secondary products of unstable $b$ ions and, in the examples presented here, those $b$ ions are stable. With the exception of the Gly-containing peptides, no $a$. ions were observed in the ECD mass spectra. The ECD behavior of the Gly-containing peptides (Figures 5 and 6; Tables 5 and 6) was characterized by extensive secondary fragmentation. The $b$ fragments observed following ECD of the Gly-containing peptides were accompanied by water loss. Water loss from $b$ ions is typically observed for peptides containing an $-\mathrm{OH}$ moiety in the amino acid side chain, for example, serine. A possible explanation for the water loss observed in the Gly peptides is that the $b$ ions observed here do not have oxonium or acylium structures, but protonated diketopiperazine structures $[48,49]$, which do contain an $-\mathrm{OH}$ moiety. The extent of $b$ fragmentation, in terms of sequence coverage, was also greater for the Glycontaining peptides. Moreover, the ECD spectra of these peptides revealed $c / z$-type cleavage within the proline residue (which was not observed for any of the other peptides studied). Those observations may be rationalized by consideration of the lack of side chains in the glycine residues and, hence, secondary structure in the peptide ions.

Another possible explanation for the presence of $b$ ions is as follows: Hydrogen atom loss is a common fragmentation channel following electron capture by peptides. It is conceivable, therefore, that the mechanism for $b$ ion formation involves electron capture by $[\mathrm{M}+n \mathrm{H}]^{n+}$ with concomitant energy deposition and hydrogen atom loss to yield the excited $[\mathrm{M}+(n-$ $1) \mathrm{H}]^{(n-1)+}$ species. Because this species is not a radical, subsequent fragmentation occurs via the "standard" peptide bond cleavage pathway, i.e., the mobile proton pathway [50], seen in traditional MS/MS techniques. The central tenet of the mobile proton model is that fragmentation of most protonated peptides requires the involvement of a proton at the cleavage site, i.e., that the cleavages are "charge directed." As described previ- 
Table 7. Fragments observed following ECD of $[\mathrm{M}+2 \mathrm{H}]^{2+}$ ions of substance $\mathrm{P}$, Lys-substance $\mathrm{P}$, and Arg-substance $\mathrm{P}$

\begin{tabular}{|c|c|c|c|c|c|c|c|c|c|}
\hline \multicolumn{4}{|c|}{ Substance $\mathrm{P}$} & \multicolumn{3}{|c|}{ Lys-substance $P$} & \multicolumn{3}{|c|}{ Arg-substance P } \\
\hline $\begin{array}{l}\text { Fragment } \\
\text { Ion }\end{array}$ & $\mathrm{m} / \mathrm{z}_{\text {meas }}$ & $\mathrm{m} / \mathrm{z}_{\text {calc }}$ & $\Delta m / p p m$ & $m / z_{\text {meas }}$ & $\mathrm{m} / \mathrm{z}_{\text {calc }}$ & $\Delta m / p p m$ & $m / z_{\text {meas }}$ & $m / z_{\text {calc }}$ & $\Delta m / p p m$ \\
\hline$c_{4}$ & 496.3354 & 496.3360 & 1.1 & 468.3291 & 468.3298 & 1.5 & 524.3422 & 524.3421 & 0.1 \\
\hline$c_{5}$ & 624.3944 & 624.3946 & 0.3 & 596.3878 & 596.3884 & 1.0 & 652.4003 & 652.4007 & \\
\hline Parent & 674.3716 & & & 660.3685 & & & 688.3747 & & \\
\hline$c_{6}$ & 752.4537 & 752.4531 & 0.7 & 724.4477 & 724.4470 & 0.9 & 780.4610 & 780.4593 & 2.1 \\
\hline$a_{7}$ & 855.5085 & 855.5079 & 0.7 & & & & & & \\
\hline$c_{7}$ & 899.5227 & 899.5215 & 1.3 & 871.5165 & 871.5154 & 1.3 & 927.5261 & 927.5277 & 1.7 \\
\hline$c_{8}$ & 1046.5924 & 1046.5900 & 2.2 & 1018.5890 & 1018.5838 & 5.0 & 1074.5934 & 1074.5960 & 2.4 \\
\hline$z_{g}$ & 1078.5716 & 1078.5630 & 8.0 & & & & 1106.5713 & 1106.5700 & 1.2 \\
\hline$c_{9}$ & 1103.6119 & 1103.6110 & 0.8 & 1075.6085 & 1075.6053 & 3.0 & 1131.6142 & 1131.6180 & 3.3 \\
\hline$c_{10}$ & 1216.6965 & 1216.6960 & 0.4 & 1188.6969 & 1188.6893 & 6.4 & 1244.6983 & 1244.7020 & 3.0 \\
\hline$[\mathrm{M}+2 \mathrm{H}]^{+\cdot}$ & 1348.7440 & & & 1320.7380 & & & 1376.7500 & & \\
\hline
\end{tabular}

Mass spectra calibrated against the parent and charge-reduced $[\mathrm{M}+2 \mathrm{H}]^{+*}$ ions.

ously, protonation of peptides typically occurs on a basic amino acid side chain. Energy deposition results in mobilization of the proton to the peptide backbone and dissociation is induced. For peptides Lys-Leu $\mathrm{Lu}_{4}$-Pro-

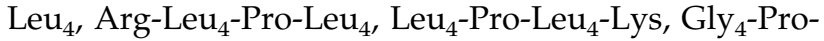
$\mathrm{Gly}_{4}$-Lys, and Gly -Pro-Gly $_{4}$-Arg, the peak corresponding to the $[\mathrm{M}+\mathrm{H}]^{+}$ions was significantly more intense than that corresponding to $[\mathrm{M}+2 \mathrm{H}]^{+}$ions, i.e., $\mathrm{H} \cdot$ loss was prevalent. For peptide $\mathrm{Leu}_{4}$-Pro-Leu 4 -Arg, the peaks corresponding to $[\mathrm{M}+\mathrm{H}]^{+}$and $[\mathrm{M}+2 \mathrm{H}]^{+\cdot}$ have approximately equivalent intensities.

Interestingly, the most abundant $b$ ions were those adjacent to the basic residues, i.e., $b_{9}$ for those peptides studied here and $b_{8}$ for the peptides in our previous study [28]. Closer inspection of the peptide studied by Chan and coworkers [32], Lys-Gly ${ }_{3}$-Trp-Gly ${ }_{3}$-Lys, reveals that the $b_{8}$ ion is observed following electron capture, i.e., the peptide bond adjacent to the C-terminal Lys residue was cleaved. Moreover, the $b$ ions observed in the ECD of $[\mathrm{M}+4 \mathrm{H}]^{4+}$ ions of Ac-(AlaLys-Ala-Ala-Lys) ${ }_{3}-\mathrm{Ala}-\mathrm{NH}_{2}$ studied by Iavorone [33] all result from cleavage of the peptide bonds adjacent to Lys residues. Electron capture is most likely to occur at

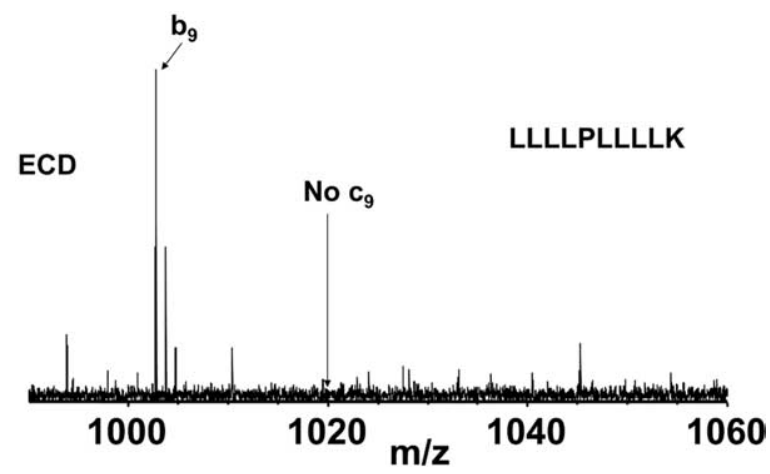

Figure 8. Selected region of ECD mass spectrum of $[\mathrm{M}+2 \mathrm{H}]^{2+}$ ions of $\mathrm{Leu}_{4}$-Pro-Leu ${ }_{4}$-Lys $\left(\mathrm{m} / \mathrm{z}\right.$ 990-1060). The $c_{9}$ fragment ion was continually ejected throughout the ECD and subsequent electron cleanup event. The $b_{9}$ ion is observed in the mass spectrum. the least basic charged site [51]. For the peptides $\mathrm{Leu}_{4}$ Pro-Leu 4 -Lys, $\mathrm{Leu}_{4}$-Pro-Leu ${ }_{4}$-Arg, Gly 4 -Pro-Gly - -Lys, and $\mathrm{Gly}_{4}-\mathrm{Pro}-\mathrm{Gly}_{4}-\mathrm{Arg}$, electron capture is predicted to occur at the N-terminus. Thus, the $b$ ion formation observed appears to reflect the position of the proton in the charge-reduced species. The $b$ ions were not observed for peptides where the basic residue was at the $\mathrm{N}$-terminus. That observation is unsurprising in light of the foregoing explanation; either additional $\mathrm{H}$ atom loss would be observed or a $b_{1}$ ion would result. The cyclic structure of $b$ ions negates the formation of $b_{1}$ ions and these species are never observed.

The presence of $b$ ions was more pronounced for Lys-containing peptides than for Arg-containing peptides. There are two points to consider. First, the recombination energies for $\mathrm{N}$-acetyl-lysine amide and $\mathrm{N}$-acetyl-arginine amide cations are 2.84 and $2.44 \mathrm{eV}$, respectively [52]. The total recombination energies depend on the conformation of the peptide ions. Valentine et al. [53] calculated that peptide ions of the form $\left[(\mathrm{Xxx})_{n} \text {-Lys }+\mathrm{H}\right]^{+}$have very similar cross sections to the analogous $\left[(\mathrm{Xxx})_{n}-\mathrm{Arg}+\mathrm{H}\right]^{+}$ ions. If the same is true of doubly charged species, and then the recombination energy would be greater for the Lys-containing peptides than the Arg-containing peptides. Thus, greater $b$ ion production would be expected for the Lys-containing peptides. Second, if the peptides are fragmenting according to the proposed mechanism, that is, $\mathrm{H} \cdot$ loss followed by peptide bond cleavage according to the mobile proton model, then the energy required for mobilization of a proton from arginine is greater than that required for mobilization from lysine. Greater fragmentation would be predicted for Lys-containing peptides.

The ECD spectra of doubly protonated substance $P$ and its analogs did not reveal any $b$ fragmentation. Unlike the other peptides studied, there are three possible charge patterns in $[\mathrm{M}+2 \mathrm{H}]^{2+}$ ions of substance P: (1) protonation at the N-terminus and Arg side chain, (2) protonation at the $\mathrm{N}$-terminus and the Lys side chain, and (3) protonation of the Arg and Lys side chains. The possible charge sites are all close to the $\mathrm{N}$-terminus; nevertheless, the $b_{2}$ 
ion might be expected if electron capture occurred at the protonated lysine (position 3). It may be that the low mass fragments are not being detected as the expected $c_{2}$ ions are also not observed in these spectra. The most stable conformer of doubly protonated substance $P$ has an internally solvated lysine side chain [54]. According to the proposed mechanism, for $b$ fragments to be produced, hydrogen atom loss, rather than transfer, must occur. For internally solvated amide carbonyl groups, however, hydrogen transfer is favored. Although peaks corresponding to $[\mathrm{M}+\mathrm{H}]^{+}$ions were observed for these three peptides, the $[\mathrm{M}+2 \mathrm{H}]^{+}$peaks predominated. Additionally, capture of an electron at the Lys residue provides recombination energy $3.7 \mathrm{eV}$, whereas capture at the Arg residue provides recombination energy $4.23 \mathrm{eV}$ [52].

The results suggest that the presence of $b$ ions in ECD spectra result from a balance of several factors. Clearly, if electron capture occurs at or adjacent to the $\mathrm{N}$-terminus, $b$ ions will not be observed. For the model peptides $\left(\mathrm{Xxx}_{n}{ }^{-}\right.$ Lys) and ( $\left.\mathrm{Xxx}_{n}-\mathrm{Arg}\right)$, whose cross sections are similar, the prevailing factors for $b$ ion production appears to be recombination energy and proton affinity. Internal solvation also appears to play a crucial role. Hydrogen atom transfer will be favored over hydrogen atom loss for internally solvated amide carbonyl groups. Syrstad and Tureček's calculations suggest that the charged guanidinium group in protonated arginine is much less effectively internally solvated than the ammonium group in protonated lysine [27]. On the other hand, more energy is required to mobilize an Arg-associated proton than a Lys-associated proton.

\section{Conclusion}

In summary, we have shown that $b$ fragment ions may result from electron capture by peptide ions. The proposed mechanism involves electron capture and energy deposition, followed by hydrogen atom loss and subsequent dissociation of the nonradical species by cleavage of the peptide backbone. Our results suggest that $b$ ions in ECD mass spectra are not the product of secondary dissociation of $c$ ions. Detection of the presence of $b$ ions in ECD spectra may be used in determining the charged site(s) in charge-reduced species. That hypothesis is corroborated by the findings of Chan and coworkers [32] and Iavarone et al. [33]. Both peptide ion conformations, recombination energy, and proton affinity appear to play roles in the electron capture-mediated production of $b$ ions.

\section{Acknowledgments}

The author thanks Dr. Alan Marshall, Dr. Mark Emmett, Dr. TuKiet Lam, and Dr. Carol Nilsson for helpful discussions and technical assistance and acknowledges the Wellcome Trust (074131) for funding. This work was supported by the NSF National High-Field FT-ICR Mass Spectrometry Facility (CHE 99-09,502), Florida State University, and the National High Magnetic Field Laboratory at Tallahassee, Florida.

\section{References}

1. Zubarev, R. A.; Kelleher, N. L.; McLafferty, F. W.; ECD of Multiply Charged Protein Cations. A Non-Ergodic Process. J. Am. Chem. Soc. 1998, 120, 3265-3266.

2. Marshall, A. G.; Hendrickson, C. L.; Jackson, G. S. Fourier Transform Ion Cyclotron Resonance Mass Spectrometry: A Primer. Mass. Spectrom. Rev. 1998, 17, 1-35.

3. Roepstorff, P.; Fohlman, J. Proposal for a Common Nomenclature for Sequence Ions in Mass Spectra of Peptides. Biol. Mass. Spectrom. 1984, 11, 601.

4. Biemann, K. Contributions of Mass Spectrometry to Peptide and Protein Structure. Biomed. Environ. Mass. 1988, 16, 99-111.

5. Zubarev, R. A.; Kruger, N. A.; Fridriksson, E. K.; Lewis, M. A.; Horn, D. M.; Carpenter, B. K.; McLafferty, F. W. ECD of Gaseous Multiply Charged Proteins is Favored at Disulfide Bonds and Other Sites of High Hydrogen Atom Affinity. J. Am. Chem. Soc. 1999, 121, 2857-2862.

6. Kelleher, N. L.; Zubarev, R. A.; Bush, K.; Furie, B.; Furie, B. C.; McLafferty, F. W.; Walsh, C. T. Localization of Labile Posttranslational Modifications by ECD: The Case of GammaCarboxyglutamic Acid. Anal. Chem. 1999, 71, 4250-4253.

7. Stensballe, A.; Jensen, O. N.; Olsen, J. V.; Haselmann, K. F.; Zubarev, R. A. ECD of Singly and Multiply Phosphorylated Peptides. Rapid. Commun. Mass. Spectrom. 2000, 14, 1793-1800.

8. Shi, S. D. -H.; Hemling, M. E.; Carr, S. A.; Horn, D. M.; Lindh, I.; McLafferty, F. W. Phosphopetide/Phosphoprotein Mapping by ECD Mass Spectrometry. Anal. Chem. 2001, 73, 19-22.

9. Mirgorodskaya, E.; Roepstorff, P.; Zubarev, R. A. Localization of O-Glycosylation Sites in Peptides by ECD in a Fourier Transform Mass Spectrometer. Anal. Chem. 1999, 71, 44314436.

10. Håkansson, K.; Cooper, H. J.; Emmett, M. R.; Costello, C. E.; Marshall, A. G.; Nilsson, C. L. ECD and IRMPD MS/MS of an N-Glycosylated Tryptic Peptide to Yield Complementary Sequence Information. Anal. Chem. 2001, 73, 4530-4536.

11. Cooper, H. J.; Heath, J. K.; Jaffray, E.; Hay, R. T.; Lam, T. T.; Marshall, A. G. Identification of Sites of Ubiquitination in Proteins: A Fourier Transform Ion Cyclotron Resonance Mass Spectrometry Approach. Anal. Chem. 2004, 76, 6982-6988.

12. Breuker, K.; Oh, H.; Cerda, B.; Horn, D. M.; McLafferty, F. W. Hydrogen Atom Loss in ECD: A Fourier Transform Ion Cyclotron Resonance Study With Single Isotopomeric ions. Eur. J. Mass. Spectrom. 2002, 8, 177-180.

13. Cooper, H. J.; Hudgins, R. R.; Håkansson, K.; Marshall, A. G. Characterization of Amino Acid Side Chain Losses in ECD. J. Am. Soc. Mass. Spectrom. 2002, 13, 241-249.

14. Hudgins, R. R.; Håkansson, K.; Marshall, A. G. Procedings of the 49th ASMS Conference on Mass Spectrometry and Allied Topics; Chicago, IL; May 2001.

15. Hudgins, R. R.; Håkansson, K.; Quinn, J. P.; Hendrickson, C. L.; Marshall, A. G. Proceedings of the 50th ASMS Conference on Mass Spectrometry \& Allied Topics; Orlando, FL; 2002.

16. Kruger, N. A.; Zubarev, R. A.; Carpenter, B. K.; Kelleher, N. L.; Horn, D. M.; McLafferty, F. W. Electron Capture Versus Energetic Dissociation of Protein Ions. Int. J. Mass Spectrom. 1999, 182/183, 1-5.

17. McLafferty, F. W.; Horn, D. M.; Breuker, K.; Ge, Y.; Lewis, M. A.; Cerda, B.; Zubarev, R. A.; Carpenter, B. K. ECD of Gaseous Multiply Charged Ions by FTICR. J. Am. Soc. Mass. Spectrom. 2000, 12, 245-249.

18. Syrstad, E. A.; Stephens, D. D.; Turecek, F. Hydrogen Atom Adducts to the Amide Bond. Generation and Energetics of Amide Radicals in the Gas Phase. J. Phys. Chem. A 2003, 107, $115-126$.

19. Syrstad, E. A.; Turecek, F. Hydrogen Atom Adducts to the Amide Bond. Generation and Energetics of the Amino(Hy- 
droxyl) Methyl Radical in the Gas Phase. J. Phys. Chem. A 2001, 105, 11144-11155.

20. Takayama, M. N-Calpha Bond Cleavage of the Peptide Backbone via Hydrogen Abstraction. J. Am. Soc. Mass. Spectrom. 2001, 12, 1044-1049.

21. Turecek, F. $N-C \alpha$ Bond Dissociation Energies and Kinetics in Amide and Peptide Radicals. Is the Dissociation a NonErgodic Process? J. Am. Chem. Soc. 2003, 125, 5954-5963.

22. Turecek, F.; Syrstad, E. A. Mechanisms and Energetics of Intramolecular Hydrogen Transfer in Amide and Peptide Radicals and Cation Radicals. J. Am. Chem. Soc. 2003, 125, 3353-3369.

23. Zubarev, R. A.; Haselmann, K. F.; Budnik, B. A.; Kjeldsen, F.; Jensen, F. Towards an Understanding of the Mechanism of Electron Capture Dissociation: A Historical Perspective and Modern Ideas. Eur. J. Mass. Spectrom. 2002, 8, 337-349.

24. Breuker, K.; Oh, H.; Lin, C.; Carpenter, B. K.; McLafferty, F. W. Nonergodic and Conformational Control of the Electron Capture Dissociation of Protein Cations. Proc. Nat. Acad. Sci. 2004, 101, 14011-14016.

25. Bakken, V.; Helgaker, T.; Uggerud, E. Models of Fragmentations Induced by Electron Attachment to Protonated Peptides. Eur. J. Mass. Spectrom. 2004, 10, 625-638.

26. Al-Khalili, A.; Thomas, R.; Ehlerding, A.; Hellberg, F.; Geppert, W. D.; Zhaunerchyk, V.; Uggerud, E.; Vedde, J.; Adlhart, C.; Semaniak, J.; Kaminska, M.; Zubarev, R. A.; Kjeldsen, F.; Andersson, P. U.; Oesterdahl, F.; Bednarska, V. A.; Paal, A. Dissociative Recombination Cross Section and Branching Ratios of Protonated Dimethyl Disulfide and N-Methylacetamide. J. Chem. Phys., 2004, 121, 5700-5708.

27. Syrstad, E. A.; Turecek, F. Towards a General Mechanism of Electron Capture Dissociation. J. Am. Soc. Mass. Spectrom. 2004, $16,208-224$

28. Cooper, H. J.; Hudgins, R. R.; Håkansson, K.; Marshall, A. G.; Secondary Fragmentation of Linear Peptides in Electron Capture Dissociation. Int. J. Mass. Spectrom. 2003, 228, 723-728.

29. Kjeldsen, F.; Haselmann, K. F.; Budnik, B. A.; Jensen, F.; Zubarev, R. A. Dissociative Capture of Hot (3-13 eV) Electrons by Polypeptide Polycations: An Efficient Process Accompanied by Secondary Fragmentation. Chem. Phys. Lett. 2002, 356, 201-206.

30. Polfer, N. C.; Haselmann, K. F.; Zubarev, R. A.; Langridge-Smith, P. R. R. ECD of Polypeptides Using a 3 T FT-ICR Mass Spectrometer. Rapid Commun. Mass. Spectrom. 2002, 16, 936-943.

31. Chan, T. -W. D.; Ip W. H. H. Optimization of Experimental Parameters for ECD of Peptides in a Fourier Transfrom Mass Spectrometer. J. Am. Soc. Mass Spectrom. 2002, 13, 1396-1406.

32. Fung, Y. M. E.; Duan, L.; Chan, T. -W. D. A Comparative Study of the Collision-Induced Dissociation and the Electron Capture Dissociation of Model Peptides Using Electrospray Ionization Fourier Transform Mass Spectrometry. Eur. J. Mass. Spectrom. 2004, 10, 449-457.

33. Iavorone, A. T.; Paech, K.; Williams, E. R. Effects of Charge State and Cationizing Agent on the Electron Capture Dissociation of a Peptide. Anal. Chem. 2004, 76, 2231-2238.

34. Senko, M. W.; Hendrickson, C. L.; Pasa-Tolic, L.; Marto, J. A.; White, F. M.; Guan, S.; Marshall, A. G. Electrospray Ionization FT-ICR Mass Spectrometry at 9. 4 Tesla. Rapid. Commun. Mass. Spectrom. 1996, 10, 1824-1828.

35. Senko, M. W.; Hendrickson, C. L.; Emmett, M. R.; Shi, S. D. -H.; Marshall, A. G. External Accumulation of Ions for Enhanced Electrospray Ionization Fourier Transform Ion Cyclotron Resonance Mass Spectrometry. J. Am. Soc. Mass. Spectrom. 1997, 8, 970-976.

36. Freitas, M. A.; Meade, M. E.; Blakney, G. T.; Lam, T. T.; McFarland, M. A.; Hendrickson, C. L.; Marshall, A. G. Proceed- ings of the 53rd ASMS Conference on Mass Spectrometry and Allied Topics; San Antonio, TX; May 2004.

37. Chowdhury, S. K.; Katta, V.; Chait, B. T. An ElectrosprayIonization Mass Spectrometer with New Features. Rapid Commun. Mass. Spectrom. 1990, 4, 81-87.

38. Beu, S. C.; Laude, D. A.; Jr. Open Trapped Ion Cell Geometries for FT/ICR/MS. Int. J. Mass. Spectrom. Ion Proc. 1992, 112, 215-230.

39. Malmberg, J. H.; O’Neil, T. M. Pure Electron Plasma, Liquid, and Crystal. Phys. Rev. Letters. 1977, 39, 1333-1336.

40. Hendrickson, C. L.; Quinn, J. P.; Emmett, M. R.; Marshall, A. G. Proceedings of the 49th ASMS Conference on Mass Spectrometry and Allied Topics; Chicago, IL; May 2001.

41. Tsybin, Y. O.; Håkansson, P.; Budnik, B. A.; Haselmann, K. F.; Kjeldsen, F.; Gorshkov, M.; Zubarev, R. A. Improved LowEnergy Electron Injection Systems for High Rate Electron Capture Dissociation in Fourier Transform Ion Cyclotron Resonance Mass Spectrometry. Rapid Commun. Mass. Spectrom. 2001, 15, 1849-1854.

42. Marshall, A. G.; Roe, D. C. Theory of Fourier transform Ion Cyclotron Resonance Mass Spectrospcopy: Response to Frequency Sweep Excitation. J. Chem. Phys. 1980, 73, 1581-1590.

43. Senko, M. W.; Canterbury, J. D.; Guan, S.; Marshall, A. G. A High-Performance Modular Data System for FT-ICR Mass Spectrometry. Rapid Commun. Mass. Spectrom. 1996, 10, 1839-1844.

44. Ledford, E. B. Jr.; Rempel, D. L.; Gross, M. L. Space Charge Effects in Fourier Transform Mass Spectrometry. Mass Calibration. Anal. Chem. 1984, 56, 2744-2748.

45. Shi, S. D. -H.; Drader, J. J.; Freitas, M. A.; Hendrickson, C. L.; Marshall, A. G. Comparison and Interconversion of the Two Most Common Frequency-to-Mass Calibration Functions for Fourier Transform Ion Cyclotron Resonance Mass Spectrometry. Int. J. Mass Spectrom. 2000, 195/196, 591-598.

46. Blakney, G. T.; van der Rest, G.; Johnson, J. R.; Freitas, M. A.; Drader, J. J.; Shi, S. D. -H.; Hendrickson, C. L.; Kelleher, N. L.; Marshall, A. G. Proceedings of the 49th ASMS Conference on Mass Spectrometry and Allied Topics; Chicago, IL; May 2001.

47. Håkansson, K.; Emmett, M. R.; Hendrickson, C. L.; Marshall, A. G. High-Sensitivity ECD Tandem FTICR Mass Spectrometry of Microelectrosprayed Peptides. Anal. Chem. 2001, 73, 3605-3610.

48. Cordero, M. M.; Houser, J. J.; Wesdemiotis, C. The Neutral Products Formed During Backbone Fragmentations of Protonated Peptides in Tandem Mass Spectrometry. Anal. Chem. 1993, 65, 1594-1601.

49. Haselmann, K. F.; Budnik, B. A.; Zubarev, R. A. ECD of $b^{2+}$ Peptide Fragments Reveals the Presence of the Acylium Ion Structure. Rapid Commun. Mass. Spectrom. 2000, 14, 2242-2246.

50. Wysocki, V. H.; Tsaprailis, G.; Smith, L. L.; Breci, L. A. Mobile and Localised Protons: A Framework for Understanding Peptide Dissociation. J. Mass. Spectrom. 2000, 35, 1399-1406.

51. Kjeldsen, F.; Adams, C. M.; Zubarev, R. A. Proceedings of the 53rd ASMS Conference on Mass Spectrometry and Allied Topics, San Antonio, TX; June 2005.

52. Mihalca, R.; Kleinnijenhuis, A. J.; McDonnell, L. A.; Heck, A. J. R.; Heeren, R. M. A. ECD at Low Temperatures Reveals Selective Dissociations. J. Am. Soc. Mass. Spectrom. 2004, 15, 1869-1873.

53. Valentine, S. J.; Counterman, A. E.; Hoaglund-Hyzer, C. S.; Clemmer, D. E. Intrinsic Amino Acid Size Parameters From a Series of 113 Lysine-Terminated Tryptic Digest Peptide Ions. J. Phys. Chem. B 1999, 103, 1204-1207.

54. Gill, A. C.; Jennings, K. R.; Wyttenbach, T.; Bowers, M. T. Conformations of Bioploymers in the Gas-Phase: A New Spectrometric Method. Int. J. Mass Spectrom. 2000, 195/196, 685-697. 